\title{
PRODUCT-LEVEL ANALYSIS OF RELATIONSHIP BETWEEN CZECH KORUNA AND CZECH FOREIGN TRADE
}

\author{
Jana Šimáková \\ Department of Finance and Accounting, School of Business Administration in Karviná, \\ Univerzitní náměstí 1934/3, 73340 Karviná, Czech Republic \\ E-mail: simakova@opf.slu.cz
}

\begin{abstract}
Paper is aimed to evaluate effects of exchange rates on the Czech bilateral trade divided into product categories. Paper assumes that different traded product categories are characterized by different price elasticity and every market consists of different consumer and producer behavior patterns, so the study applies territorial and commodity approach to foreign trade disaggregation. Long term effects are assessed by Johansen cointegration and short term effects by vector error correction model. Analysis for the period $1999-2014$ on the SITC 1 and 2 digit data shows that bilateral and majority of commodity trade balances are cointegrated with bilateral exchange rate.
\end{abstract}

Keywords: exchange rate change, bilateral trade, foreign trade, J-curve, cointegration, sector analysis.

JEL Classification: F31; F10; F14.

\section{Introduction}

Effects of the Czech koruna (CZK) exchange rate development on the international trade of the Czech Republic serves an interesting view on complex interrelationships on the international trading markets. This paper focuses on a small open economy located in Central Europe, which has successfully completed the transition process to the market economy. After significant political transformation and reforms, it experienced significant changes in its foreign trade issues as well. This process began with redirecting trade from east to west, thus the structure and intensity of trade flows has significantly changed. Its initial limited interaction with the world economy was based more on the state restrictions then the market decisions and prices. Nowadays this former member of relatively isolated trade bloc has turned into a country which partly forms the world foreign trade and its involvement in international trade flows has been increasing (approximately $150 \%$ openness in 2015). The transformation process also reflected in the development of foreign exchange rates. Country abandoned the fixed currency system and moved toward floating. However, the CZK/EUR exchange rate has been adopted by the Czech National Bank as a monetary policy instrument since November 2013.

The currency development has two basic effects on export and imports flows - price and volume effect. Depreciation generally results in the export prices reduction. Simultaneously, the demanded quantity for them usually increase. Vice versa, the import prices rises, what causes the decrease the overall traded volume. The total effect of exchange rate change on trade balance depends on the Marshall-Lerner condition. Depreciation can cause the improvement of the trade balance only if this condition is valid. This premise is mostly not fulfilled in the short term perspective. The sum of export and import demand elasticity equal or higher than 1 can be generally observed in longer period. The time resolution is therefore one of the crucial assumption in assessing of the currency development effects on foreign trade.

Although the application of the J-curve principle motivated many researchers to publish several studies, this paper also fully addresses the criticism of using cumulative foreign trade data (e.g., Rose, Yellen 1989). The study assumes that different traded product categories are characterized by different price elasticity and every market consists of different consumer and producer behavior patterns, so the study applies the territorial and commodity approach to foreign trade disaggregation. Paper is aimed to evaluate effects of exchange rates on the Czech bilateral trade divided into product categories.

\section{Theoretical background and literature review}

The J-curve theory is based on the Marshall-Lerner condition. This means that the sum of demand elasticities of export and import flows has to be 
equl or at least one. The currency depreciation then results in a positive effect on trade balance. Empirical examination of the Marshall-Lerner condition shows that from the short run perspective, goods tend to be inelastic, as it takes time to change consuming behaviour (Bahmani-Oskooee, Ratha 2004). Therefore, depreciation can worsen the trade balance initially. In the longer period, individuals start to change consuming patterns in relations to the new prices and trade balance improves. Magee (1973) pointed out that the initial deterioration followed by improvement of the trade balance graphically look like a letter "J".

The J-curve effect can be attributed to lags in the recognition of price changes, in the result of real variables changes, in contract period, in the replacement of product resources, and in a finalmanufacture (Junz and Rhomberg 1973). Krueger (1983) explaines the phenomenon by the statement that in case of change of exchange rate, goods purchased under long term contract are already in shipment and thsese trades dominates. Therefore, currency depreciation deteriorates the trade balance firstly, but improves it gradually.

The J-curve effect is subject of many empirical researches. However, their findings are mixed. It differs across economies, sample periods, data collection and applied models.

Generally this studies can be divided in following categories:

Aggregate trade data analysis, e.g.: BahmaniOskooee (1989), Himarios (1989), Rose (1990), Mahdavi and Sohrabian (1993), Bahmani-Oskooee and Alse (1994).

Bilateral trade data analysis, e.g.: Rose and Yellen (1989), Bahmani-Oskooee and Brooks (1999), Arora et al. (2003), Bahmani-Oskooee and Ratha (2004), Bahmani-Oskooee et al. (2006).

Industry/commodity data analysis, e.g.: Doroodian et al. (1999), Bahmani-Oskooee and Ardalani (2006).

Disaggretated data at bilateral and product level analysis, e.g.: Bahmani-Oskooee and Wang (2007), Breuer and Clements (2003), BahmaniOskooee and Hegerty (2011), Bahmani-Oskooee et al. (2014).

Studies employing total foreign trade data between aneconomy and the rest of the world in combination with an effective exchange rate are generally critized due to aggregation bias. The needed construction of the world GDP can cause a problem in calculation (Rose, Yellen 1989). The studies based on bilateral trade data, however, do not satisfy the issue of differences in tested relationship across the industries and do not take the differences between market structures into account. Hence, the newest studies divide the trade also on the product level. The availability of more detailed data allows to use exchange rates and productlevel.

In studies concerning the J-curve issue can be found only few focusing on the Czech Republic. Bahmani-Oskooee and Kutan (2009) included Czechia in the study for the period 1990-2005. By applying autoregressive distributed lag cointegration methdology, they do not find any empirical evidence for the J-curve phenomenon in the Czech case. Nusair (2013) applied a similar methodology on for seventeen emerging and transitioning economies in the period 1991-2012. Czech economy again remained free of the support for the J-curve.

We can find some characteristics of the J-curve effect in studies on the country to country level. Hacker and Hatemi (2004) came to the conclusion that the Czech trade balance with Germany deteriorates at the beginning after depreciation. However, there is observed increase in the long run. This conclusion was confirmed by Šimáková (2012) as well.

On the contrary, Hsing (2009) found no evidence of this effect in trade between the Czech republic and USA. Šimáková (2014) discusses problems arising from the use of aggregated data and in the case of Slovakia demonstrates the effect of the distortion of the results caused by the aggregation of data. While at the aggregate level during the period 1997-2013 is revealed an inverse J-curve, effects on bilateral level are ambiguous and for trade with Hungary even demonstrate their conformity with the effect of a classic J-curve.

A product-level studies have so far been applied to the Czech Republic during 1993-2013. Simáková and Stavárek (2015) confirm by Johansen cointegration test the presence of long-term relationship with the exchange rates for almost all the sub-trade balance of the Czech Republic and demonstrate beneficial effects of depreciation. Vector error correction model in this case do not show almost no statistically significant relationships.

In empirical literature can be found on one hand studies which confirm the J-curve theory (e.g. Mahdavi, Sohrabian 1993), but also studies we the opposite results on the other hand (e.g. Felrningham 1988). Moreover, whereas in some countries, a some studies reveal the same effect, in some countries, the results of different studies are inconsistent. Hence the analyzed period and econometric techniques used in the examination of the J-curve effect can definitely influence the conclusions. 


\section{Model and data specification}

This paper analyzes impact of currency development on Czech foreign trade for the period 1999:Q1 - 2014:Q4. Analyzes covers the newest available data after the most turbulent part of economic trasformation which can distort the testing. It distinguishes foreign trade at two levels, namely the territory and product. Territorial composition of foreign trade is understood as a share of countries on total trade operations expressed in value. By the territorial view can be seen which countries are the most important importers and exporters of Czechia. The bilateral analysis uses cross-border data between the Czech Republic and its six major trading partners.

The selection of partner countries represents $58 \%$ of the aggregate foreign trade turnover of the Czech Republic in the analysed sample period. Figure 1 shows the shares of major trading partners on Czech total foreign trade turnover. It can be seen that approximately $30 \%$ of total trade is realized with Germany (DE). Foreign trade is so clearly influenced by german economic development, although it must be noted that the share is decreasing in time. Slovakia (SK) is the second most important foreign market. Bilateral trade between these two countries is based on the long-term economic ties. Other important trading partners are Austria (AT), France (FR), Italy (IT) and Poland (PL). In general, the Czech Republic implements foreign trade thanks to barrier-free trade with EU countries (almost $80 \%$ on average). Among

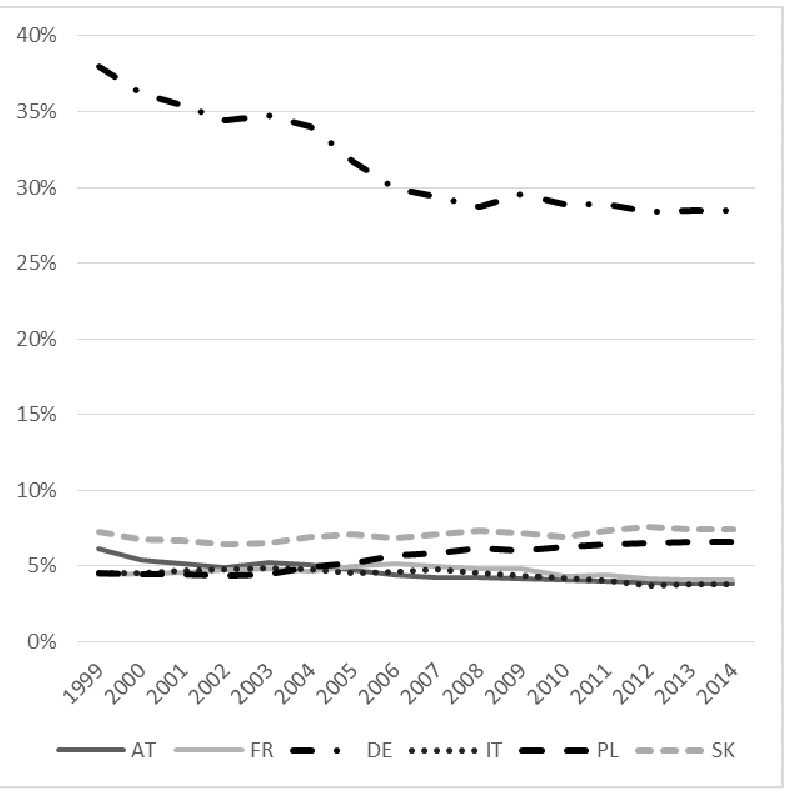

Fig. 1. Territorial Structure of Czech Foreign Trade (Source: authors' calculations based on data obtained from OECD database) major trading partners belonging to non-EU countries with lower share on its foreign trade are markets supplying goods in lower price levels (USA, China), long-term strategic partners (Russia) or territory of foreign direct investment (South Korea). However, their shares are not so significant and are excluded from the analysis.

Product-level view on the foreign trade monitors shares of individual product categories on total imports and exports. Classification of commodities used in the paper is determined by the Standard International Trade Classification (SITC), which divides traded goods in the 10 sections and then to divisions. Result of this classification is the segmentation of the commodities not only by the type of material from which they occurred but also by their economic purpose and level of processing. Tested 1 and 2 digit SITC classes are as follows:

0 Food and live animals

00 Live animals other than animals

01 Meat and meat preparations

02 Dairy products and birds' eggs

03 Fish, crustaceans, molluscs

04 Cereals and cereal preparations

05 Vegetables and fruit

06 Sugars, sugar preparations and honey

07 Coffee, tea, cocoa, spices, and manufactures

08 Feeding stuff for animals

09 Other edible products and preparations

1 Beverages and tobacco

11 Beverages

12 Tobacco and tobacco manufactures

2 Crude materials, inedible, except fuels

21 Hides, skins and furskins, raw

22 Oil-seeds and oleaginous fruits

23 Crude rubber

24 Cork and wood

25 Pulp and waste paper

26 Textile fibres

27 Crude fertilizers

28 Metalliferous ores and metal scrap

29 Crude animal and vegetable materials

3 Mineral fuels, lubricants and related materials

32 Coal, coke and briquettes

33 Petroleum, petroleum products

34 Gas, natural and manufactured

35 Electric current

4 Animal and vegetable oils, fats and waxes

41 Animal oils and fats

42 Fixed vegetable fats and oils, crude

43 Animal or vegetable fats and oils

5 Chemicals and related products, n.e.s.

51 Organic chemicals 
52 Inorganic chemicals

53 Dyeing, tanning and colouring materials

54 Medicinal and pharmaceutical products

55 Essential oils, resinoids, perfume materials

56 Fertilizers

57 Plastics in primary forms

58 Plastics in non-primary forms

59 Chemical materials and products, n.e.s.

6 Manufactured goods classified by material

61 Leather, dressed furskins

62 Rubber manufactures, n.e.s.

63 Cork and wood manufactures

64 Paper, paperboard and articles of paper pulp

65 Textile yarn, fabrics, made-up articles, n.e.s.

66 Non-metallic mineral manufactures, n.e.s.

67 Iron and steel

68 Non-ferrous metals

69 Manufactures of metals, n.e.s.

7 Machinery and transport equipment

71 Power-generating machinery and equipment

72 Machinery specialized for particular industries

73 Metalworking machinery

74 General industrial machinery and equipment

75 Office and automatic dataprocessing machines

76 Telecommunications, recording equipment

77 Electrical machinery, apparatus, appliances

78 Road vehicles (including air-cushion vehicles)

79 Other transport equipment

8 Miscellaneous manufactured articles

81 Prefabricated buildings; sanitary, plumbing, heating and lighting fixtures and fittings, n.e.s.

82 Furniture, bedding, mattresses, mattress supports, cushions and similar stuffed furnishings

83 Travel goods, handbags and similar containers

84 Articles of apparel and clothing accessories

85 Footwear

87 Professional, scientific, controlling instrument

88 Photographic apparatus, equipment and supplies and optical goods; watches and clocks

89 Miscellaneous manufactured articles, n.e.s.

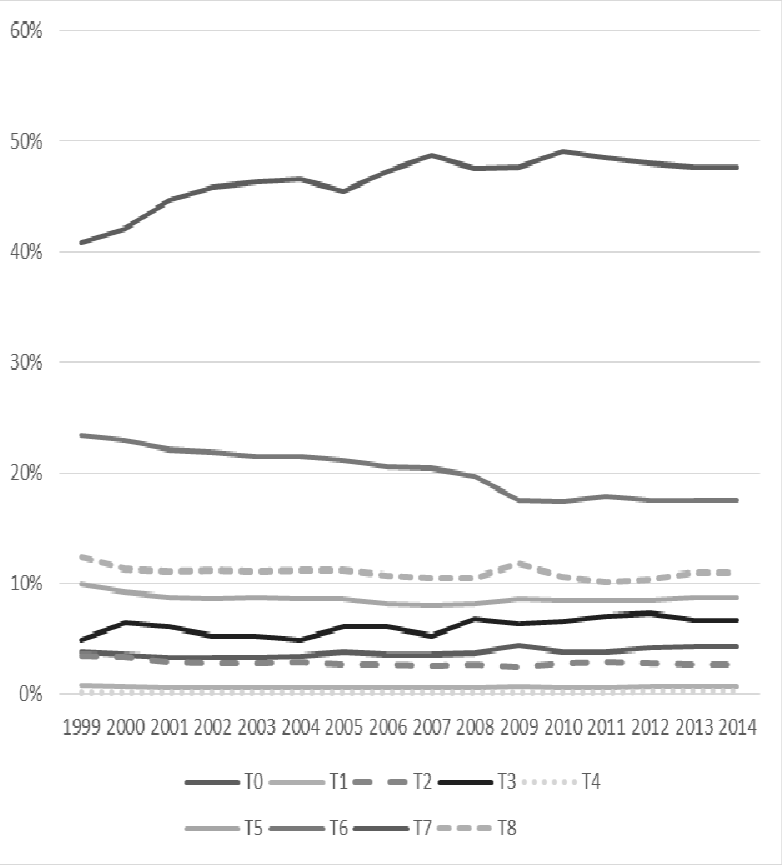

Fig. 2. Commodity Structure of Czech Foreign Trade (Source: authors' calculations based on data obtained from OECD database)

The section 9 is excluded from the analysis as it is inconsistent group of goods without any common features. The share of individual 1 digit SITC sections on total Czech foreign trade can be seen in Figure 2. There is visible dominance of traded SITC category T7, whose average share of trade flows in the sample period is $47 \%$. Another important traded category is T6, which for the Czech Republic another 20\% share, T8 group represents about $10 \%$ share. Foreign trade is concentrated in sections of manufactured goods, machinery, transport equipment and other manufactured products with higher added value.

Following Bahmani-Oskooee and Kutan (2009), model (1) is applied on the Czech case for the assessing of the long term relationship. There is applied the cointegration procedure developed by Johansen (1997). The model (1) is as follows:

$$
\ln T B(p) t=\alpha+\beta \ln Y d, t+\gamma \ln Y_{f, t}+\lambda \ln E R_{f, t}+\varepsilon t,
$$

where $T B$ represents the trade balance in time $t$; $T B p$ is the ratio in a tested product group $p . Y_{d}$ is domestic GDP; $Y_{f}$ is the GDP in partner economy $f$. GDPs are in the index form. $E R_{f}$ is the nominal bilateral exchange rate in a direct quotation. This means that increase reflects a depreciation of the domestic currency. $\varepsilon_{t}$ represents an error term.

The incorporating of short run aspects into the model above allows to test the short-run relation- 
ship. In accordance with Hsing (2009), there is applied modified vector error correction model, where $E C$ is the disequilibrium term and $\square_{k} E C_{t-1}$ is the error correction mechanism:

$$
\begin{aligned}
& \Delta \ln T B p, t=\alpha+\sum_{k=1}^{n} \varpi k \Delta \ln T B t-k+\sum_{k=1}^{n} \beta k \Delta \ln Y d, t-k+ \\
& \sum_{k=1}^{n} \gamma k \Delta \ln Y_{f, t}-k+\sum_{k=1}^{n} \lambda_{k} \Delta \ln E R f, t-k+\mathrm{v} k E C t-1+\varepsilon t
\end{aligned},
$$

Exchange rates $E R$ are ussed in direct quotations of nominal bilateral exchange rates. This is in accordance to arguments of Auboin and Ruta (2013) that the choice between nominal and real exchange rate does not affect econometric results. Data of exchange rates are derived from the Eurostat database. Income $Y_{d}$ respectively $Y_{f}$, is represented by GDP of each country in current prices. GDP is derived from the OECD database. GDP is transferred to the index form to make it unitless. Data of import and export are gained from Czech Statistical Office. All data are on quarterly frequency.

\section{Results and discussion of empirical testing}

The detect the impact of the exchange rate change on the bilateral trade balances is used a model (1). At the beginning, we performed the logarithmic transformation. This step helps to reduce skewness, to decrease the heteroscedasticity and to stabilize the variability of tested time series. Integration of variables was determined by the augmented Dickey-Fuller testing. This test confirmed the presence of unit roots in all used time series. The optimal lags $(l)$ in SITC 1 digit analysis are reported in Table 1, which also reports the number of existing cointegration equations $(r)$.

We can observe lags differentation across product categories. Greater lags are found especially for manufactured goods, machinery and transport equipment and miscellaneous manufactured articles which are generally traded under long-term contracts. Therefore it seems to adapt to new price conditions for longer time. Johansen cointegration test results say that the aggregate bilateral trade balances are in long term equilibrium in all observed cases. On the product level, we can find exceptions. Neither cointegration vector has been assesed for product category T4. $\mathrm{T} 4$ is the product category characterized by a substantially smaller share of the total foreign trade. For the analyzed period the average share is less than $0.1 \%$.
Table 1. Lags and Cointegration Equations in SITC 1 Digit Analysis (Source: authors' calculations) Note: Estimation of the SITC 2 Digit Analysis are available upon authors' request

\begin{tabular}{c|ll|ll|ll|ll|ll|ll}
\hline & AT & & DE & & FR & & IT & & PL & & SK & \\
& $l$. & $r$ & $l$. & $r$ & $l$. & $r$ & $l$. & $r$ & $l$. & $r$ & $l$. & $r$ \\
\hline $\mathrm{T}$ & 4 & 1 & 2 & 1 & 2 & 1 & 4 & 1 & 2 & 1 & 2 & 1 \\
0 & 4 & 1 & 2 & 1 & 2 & 1 & 2 & 2 & 2 & 2 & 2 & 1 \\
1 & 4 & 1 & 2 & 0 & 2 & 1 & 2 & 0 & 2 & 1 & 2 & 1 \\
2 & 4 & 1 & 2 & 1 & 3 & 1 & 2 & 1 & 2 & 2 & 2 & 1 \\
3 & 4 & 0 & 2 & 1 & 4 & 1 & 2 & 1 & 2 & 1 & 2 & 1 \\
4 & 4 & 0 & 2 & 0 & 4 & 0 & 2 & 0 & 2 & 0 & 2 & 0 \\
5 & 4 & 1 & 4 & 1 & 5 & 1 & 2 & 1 & 3 & 1 & 5 & 1 \\
6 & 5 & 0 & 4 & 1 & 9 & 1 & 5 & 0 & 2 & 1 & 5 & 1 \\
7 & 5 & 1 & 4 & 1 & 9 & 1 & 9 & 1 & 3 & 1 & 5 & 1 \\
8 & 5 & 1 & 9 & 1 & 9 & 0 & 9 & 1 & 4 & 1 & 9 & 1 \\
\hline
\end{tabular}

The territorial structure shows that less cointegration equations is revealed fro trade with AT and IT. In the case of AT we do not find long term relationship with product categories representing $31.3 \%$ of their bilateral trade, for IT it is $27.3 \%$ of mutual foreign trade. In other trading partners noncointegrated product categories represent less than $1 \%$. Therefore, it can be concluded that majority of tested trade balances are characterized by long-term joint development of Czech GDP, GDP of its trading partners, as well as a bilateral exchange rate. Analysis of the long term relationship was provided for the SITC 1 digit and 2 digit data. Analysis of long term coefficients for the Czech GDP shows significant differences not only across product categories, but also across trading partners. For the trade with AT were revealed negative effects of domestic GDP on trade balance (except product category T0 - share in total trade is with AT 3.5\%). A similar conclusion is also estimated for SK, which shows negative effect on domestic GDP on the total bilateral and also partial trade balances constituting the $74 \%$ bilateral trade. For trading partners DE, FR, IT and PL, cointegration analysis revealed the opposite relationship with Czech GDP. For trading partner IT were positive coefficients estimated also for all cointegrated partial trade balances. For other bilateral flows, the partial analysis of the effects does not support the overall results. Consistent conclusions of bilateral and product-level trade balances in the case of $\mathrm{DE}$ are in product categories representing only $19 \%$ and $29 \%$ for FR and PL for $36 \%$ of total bilateral foreign trade. The results thus clearly show the possible aggregation bias. 
Table 2. Estimation of the Long-Run Trade Models (Source: authors' calculations)

\begin{tabular}{c|ccc|ccc|ccc|ccc|ccc|ccc}
\hline & \multicolumn{3}{|c|}{ AT } & \multicolumn{3}{|c|}{ DE } & \multicolumn{3}{c|}{ FR } & \multicolumn{3}{c|}{ GB } & & IT & \multicolumn{3}{c}{ PL } \\
\cline { 2 - 14 } & Y d & Y f & ER & Y d & Y f & ER & Y d & Y f & ER & Y d & Yf & ER & Y d & Y f & ER & Y d & Y f & ER \\
\hline T & 2.41 & -7.37 & 8.89 & -0.63 & 0.91 & -0.09 & -10.60 & 9.13 & -1.11 & -0.52 & 1.44 & -0.17 & -2.58 & 8.13 & -1.18 & 0.16 & -0.49 & 1.75 \\
0 & - & - & - & & 1.84 & 1.49 & -4.42 & 6.18 & -4.86 & 7.19 & -11.44 & 1.23 & -2.69 & 6.42 & 1.04 & -1.11 & 0.10 & 1.42 \\
1 & 1.48 & -2.06 & 2.94 & 2.74 & 8.26 & -0.24 & -6.65 & 2.07 & 0.05 & - & - & - & -5.58 & 10.37 & 1.19 & -1.91 & 3.01 & -1.50 \\
2 & -0.96 & 4.56 & -0.19 & - & - & - & - & - & - & - & - & - & 0.42 & -0.24 & 1.89 & & 1.46 & -1.50 \\
3 & 2.99 & -10.32 & 9.13 & - & - & - & - & - & - & - & - & - & - & - & - & - & - & - \\
4 & - & - & - & - & - & - & - & - & - & - & - & - & - & - & - & - & - & - \\
5 & -0.00 & -0.66 & 2.79 & -2.89 & 1.12 & -0.83 & -0.30 & 6.40 & -1.14 & - & - & - & -0.08 & 6.76 & -0.91 & - & - & - \\
6 & -0.14 & -1.86 & 0.73 & -4.65 & 12.81 & 1.86 & 2.14 & -5.67 & 0.79 & - & - & - & & -0.98 & 1.23 & -0.12 & 0.08 & 0.89 \\
7 & - & - & - & & 0.17 & 0.47 & -7.70 & 4.94 & -1.64 & -1.17 & 2.27 & -0.39 & & 2.20 & -1.91 & & -2.10 & 1.78 \\
8 & 0.24 & -2.24 & 0.29 & -2.32 & 2.34 & -2.84 & 6.18 & 2.23 & -2.07 & 8.61 & 4.60 & -1.75 & - & - & - & & -0.47 & 0.04 \\
\hline
\end{tabular}

Estimated coefficients of foreign GDP provide clearer conclusions. All trading partners have the positive effect of their GDP on total bilateral trade balance of the Czech Republic. Increase of income in foreign economies can thus be approximated with an improvement of the purchasing power of investors, increasing the demanded volume of domestic goods abroad and therefore an increase in exported goods. The highest rate was demonstrated for Slovak GDP, which clearly shows the interdependence of these economies. However, on the commodity level, you can also find the opposite effect. In the case of trade with AT these product categories represent $38 \%$ of bilateral trade, in trade with $\mathrm{DE}$ it is $8 \%$ market share, in case of FR it is the categorie with $12 \%$ share, the SK categories represent $23 \%$ share, the PL categories $37 \%$ share ana IT categories up to $57 \%$ share of bilateral foreign trade.

The results presented in Table 2 also show that the positive coefficient for a variable of exchange rate can be found in trade with DE, IT and PL. These estimates are supported by expected positive impact of the currency depreciation of the Czech koruna on its partial trade balances. Total average share of these partners in the Czech total foreign trade turnover in the tested period was $39 \%$. For tading partner AT is bilateral negative coefficient supported also by the estimation on the commodity level (except T0 category). For other partial trade balances are the effects of exchange rate mixed. The positive effects of depreciation is proved in SITC 2 digit analysis for $79 \%$ share of trade with DE, $77 \%$ share of trade with PL and $53 \%$ share of trade with SK.
Table 3. Short Term Effects of Currency Depreciation (Source: authors' calculations)

\begin{tabular}{l|c|l|l}
\hline $\begin{array}{c}\text { Effect of } \\
\text { depreciation }\end{array}$ & SITC & Bilateral trade & J-curve \\
\hline Negative & T & AT & \\
0 & DE, IT, PL, & IT, PL \\
2 & SK & \\
& 3 & AT & FR, PL \\
& 6 & DE, FR, PL, & PL \\
& 7 & SK & \\
Positive & 2 & PL & \\
& 5 & AT, PL & \\
& 6 & FR, PL, SK & \\
& 7 & FR, SK & \\
& 8 & DE, FR, SK & \\
& & DE, IT & AT, IT, PL, \\
& & SK & \\
\hline
\end{tabular}

As already mentioned, the short-run coefficients are reflected in the estimates acquired for the lagged value of the first difference of exchange rate time series. Given the theoretical assumtions, we expect the statistically significant negative coefficient of exchange rate at lower lags followed by a statistically significant positive ones at longer lags. In another words, the J-curve is confirmed by the negative short-run coefficients, followed by the positive ones in the long-run models. The statistically significant short-term coefficients are detected only rarely by the vector correction model. The short-run significant negative coefficient followed by positive improvement supporting the J-curve theory can be found in trade balance of food, live animals with partners Italy and Poland, for trade balance of mineral fuels, lubricants and related ma- 
terials with partners France and Poland and for trade balance trade of manufactured goods with Poland (see Table 3).

Results of this study show disunity with economic theory in some ways and cannot be clearly generalized. Ambiguous effects of currency development on bilateral trade which do not verified the economic theory can result from numerous features of Czech participation in global commodity movements. Czech Republic has import-intensive exports, the share of imported goods in GDP suggests the economies heavily dependent on imports. Another typical feature is a significant presence of foreign direct investment. Many foreign companies with subsidiary branches in countries surveyed include multinational corporations operating on different territories. This fact implies their strong involvement in export and import transactions within multinational companies. World economic environment is constantly changing and the current trend of global supply chains and multinational companies is also accompanied by an expansion of the total international trade flows due to intermediate crossing national borders several times during production. National export competitiveness often depends on the availability of imported inputs, while some imported products contain originally exported commodities processed abroad. Depreciation may therefore have a negative impact on national export sector. Analogously, the cost of exchange rate changes may be higher, as intermediates must overcome several borders. In this situation, the effects of currency on foreign trade can vary significantly.

\section{Conclusions}

Paper is aimed to evaluate effects of exchange rates on the Czech bilateral trade divided into product categories. Paper assumed that different traded product categories are characterized by different price elasticity and every market consists of different consumer and producer behavior patterns, so the study applied territorial and commodity approach to foreign trade disaggregation. To distinguish the tested effects in time, the J-curve phenomenon was empirically applied. Long term effects were assessed by Johansen cointegration and short term effects by vector error correction model. Analysis was provided for the period 1999:Q1 to 2014:Q4. Product groups were based on the SITC 1 and 2 digit classification.

Applying of this methodology showed the cointegration between bilateral, majority of commodity trade balances and currency development of Czech koruna. In other words, there is indicated tendency for common movement from the long run perspective. The results from the short term analysis can not be generalized across different product categories. The short-run significant negative coefficient followed by positive improvement supporting the J-curve theory can be found in trade balance of food, live animals with partners Italy and Poland, for trade balance of mineral fuels, lubricants and related materials with partners France and Poland and for trade balance trade of manufactured goods with Poland. For the rest tested trade balances, J-curve effect is not revealed by the estimated coefficients of exchange rates.

The effects of currency depreciation are less than ambiguous and cannot be generalized across the analyzed product categories but in the sample period, increasing in trade balances after currency depreciation dominates its decreasing and exchange rate as a macroeconomic tool can represent an effective instrument of stimulating the foreign trade.

\section{Acknowledgement}

Publication of this paper was supported by the Internal Grant System of Silesian University in Opava (IGS/22/2016).

\section{Disclosure statement}

Author declares that she has not any competing financial, professional, or personal interests from other parties.

\section{References}

Arora, S.; Bahmani-Oskooee, M.; Goswami, G. 2003. Bilateral J-curve between India and her trading partners, Applied Economics 35(9): 1037-1041. http://dx.doi.org/10.1080/0003684032000102172

Auboin, M.; Ruta, M. 2013. The relationship between exchange rates and international trade: a literature review, World Trade Review 12(3): 577-605. http://dx.doi.org/10.1017/S1474745613000025

Bahmani-Oskooee, M. 1989. Devaluation and the J-Curve: some evidence from LDCs, The Review of Economics and Statistics 67(3): 500-504. http://dx.doi.org/10.2307/1925980

Bahmani-Oskooee, M.; Alse, J.1994. Short-run versus long-run effects of devaluation: error correction modeling and cointegration, Eastern Economic Journal 20(4): 453-464.

Bahmani-Oskooee, M.; Ardalani, Z. 2006. Exchange rate sensitivity of U.S. trade flows: evidence from industry data, Southern Economic Journal 72(3): 542-559. http://dx.doi.org/10.2307/20111832 
Bahmani-Oskooee, M.; Brooks, T.J. 1999. Bilateral J-Curve between U.S. and her trading partners, Review of World Economics 135(1): 156-165. http://dx.doi.org/10.1007/bf02708163

Bahmani-Oskooee, M.; Economidou, C.; Goswami, G.G. 2006. Bilateral J-curve between the UK visa-vis her major trading partners, Applied Economics 38(8): 879-888.

http://dx.doi.org/10.1080/00036840500399388

Bahmani-Oskooee, M.; Harvey, H.; Hegerty, S. 2014. Brazil-US commodity trade and the J-Curve, Applied Economics 46(1): 1-13. http://dx.doi.org/10.1080/00036846.2013.824548

Bahmani-Oskooee, M.; Hegerty, S. W. 2011. The J-curve and NAFTA: evidence from commodity trade between the U.S. and Mexico, Applied Economics 43(13): 1579-1593. http://dx.doi.org/10.1080/00036840802360328

Bahmani-Oskooee, M.; Kutan, A. 2009. The J-curve in the emerging economies of Eastern Europe, $A p$ plied Economics 41(20): 2523-2532. http://dx.doi.org/10.1080/00036840701235696

Bahmani-Oskooee, M.; Ratha, A. 2004. The J-curve: a literature review, Applied Economics 36(13): 1377-1398. http://dx.doi.org/10.1080/0003684042000201794

Bahmani-Oskooee, M.; Wang, Y. 2007. The impact of exchange rate volatility on commodity trade between the U.S. and China, Economic Issues 12(1): 31-52.

Breuer, J. B.; Clements, L. A. 2003. The commodity composition of US-Japanese trade and the Yen/Dollar real exchange rate, Japan and the World Economy 15(3): 307-330. http://dx.doi.org/10.1016/S0922-1425(02)00052-X

Doroodian, K.; Jung, C.; Boyd, R. 1999. The J-curve effect and US agricultural and industrial trade, $A p$ plied Economics 31: 687-695. http://dx.doi.org/10.1080/000368499323904

Felrningham, B. 1988. Where is the Australian J-curve? Bulletin of Economic Research 40(1): 43-56.

http://dx.doi.org/10.1111/j.1467-8586.1988.tb00253.x

Hacker, R.; Hatemi, J. A. 2004. The effect of exchange rate changes on trade balances in the short and long run. Evidence from German trade with transitional Central European economies, The Economics of Transition 12(4): 777-799.

http://dx.doi.org/10.1111/j.0967-0750.2004.00202.x

Himarios, D. 1989. Do devaluations improve the trade balance? The evidence revisited, Economic Inquiry 27(1): 143-168.

http://dx.doi.org/10.1111/j.1465-7295.1989.tb01169.x
Hsing, Y. 2009. Test of the J-curve for six selected new EU countries, International Journal of Economic Policy in Emerging Economies 2(1): 76-85. http://dx.doi.org/10.1504/IJEPEE.2009.022942

Johansen, S. 1997. Likelihood-based interference in cointegrated vector autoregressive models. Oxford: Oxford University Press.

Junz, H.; Rhoemberg, R. R. 1973. Price competitiveness in export trade among industrial countries, Papers and Proceedings of American Economic Review 63(5): 412-418.

Krueger, A. 1983. The factor proportions explanation of trade, distortions, and employment, in Trade and employment in developing countries. Cambridge: National Bureau of Economic Research.

Magee, S. P. 1973. Currency contracts, pass through and devaluation, Brooking Papers on Economic Activity 1(1): 303-325. http://dx.doi.org/10.2307/2534091

Mahdavi, S.; Sohrabian, A. 1993. The exchange value of the Dollar and the US trade balance: an empirical investigation based on cointegration and Granger causality tests, The Quarterly Review of Economics and Finance 33(4): 343-358. http://dx.doi.org/10.1016/1062-9769(93)90003-3

Nusair, S. A. 2013. The J-curve in Transition Economies: an Application of the ARDL Model. New Orleans: Academic and Business Research Institute.

Rose, A. K. 1990. Exchange rates and the trade balance: some evidence from developing countries, Economics Letters 34: 271-275. http://dx.doi.org/10.1016/0165-1765(90)90130-S

Rose, A. K.; Yellen, J. L. 1989. Is there a J-curve?, Journal of Monetary Economics 24(1): 53-68. http://dx.doi.org/10.1016/0304-3932(89)90016-0

Šimáková, J. 2014. Extended gravity model of international trade: an empirical application to Czech trade flows, in D. Stavárek; P. Vodová (Eds.). Proceedings of the $14^{\text {th }}$ International Conference on Finance and Banking. Karviná: Silesian University, School of Business Administration, 416421.

Šimáková, J. 2012. Estimation of the J-curve effect: the case of visegrad group. Istanbul: Teknik Basim Matbaacilik.

Šimáková, J.; Stavárek, D. 2015. The effect of the exchange rate on industry-level trade flows in Czechia, E+M Ekonomie a Management 18: 150165. 